\title{
Periodic fever syndrome and autoinflammatory diseases
}

\section{Laura J Dickie, Sinisa Savic, Azad Aziz, Michael Sprakes and Michael F McDermott*}

Address: NIHR-Leeds Musculoskeletal Biomedical Research Unit (NIHR-LMBRU), Leeds Institute of Molecular Medicine, Wellcome Trust Brenner Building, St. James's University Hospital, Leeds, LS9 7TF, UK

*Corresponding author: Michael F McDermott (m.mcdermott@leeds.ac.uk)

Fl000 Medicine Reports 2010, 2:3 (doi:10.3410/M2-3)

The electronic version of this article is the complete one and can be found at: http://fl000.com/reports/medicine/content/2/3

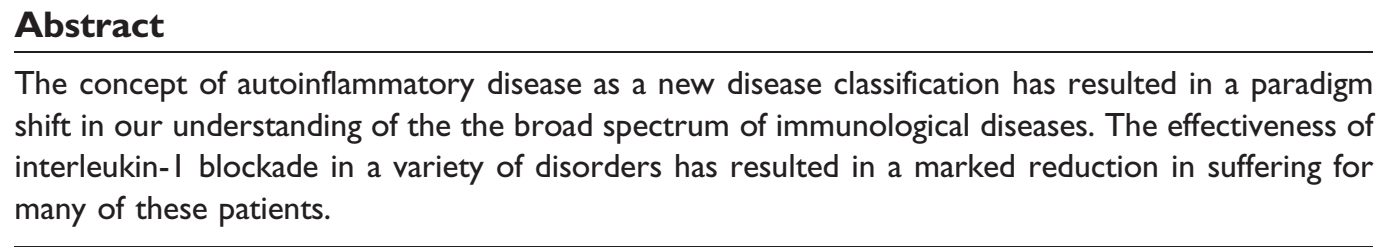

\section{Introduction and context}

Over the past 10 years a group of monogenic diseases, termed the hereditary periodic fever syndromes (HPFS), which present with recurrent inflammation and unexplained fevers as part of their phenotype, have been classified as autoinflammatory in nature, residing at the extreme of the immunological disease continuum proposed in 2006 [1]. The HPFS typically manifest in the paediatric population. There has been remarkable progress in delineation of the genetic pathways involved and successful management of these syndromes. These conditions are linked at the functional level, as the reported mutations are manifested in cells and proteins of the innate immune system. There are at least five HPFS, which include two autosomal recessive conditions, familial Mediterranean fever (FMF) and hyperimmunoglobulinemia D with periodic fever syndrome (HIDS), in addition to a group of autosomal dominant diseases, including tumor necrosis factor receptorassociated periodic syndrome (TRAPS), pyogenic arthritis, pyoderma gangrenosum, and acne (PAPA) syndrome, as well as three related conditions, collectively termed the cryopyrin-associated periodic syndromes (CAPS). Familial cold autoinflammatory syndrome (FCAS), Muckle-Wells syndrome, and neonatal onset multisystem inflammatory disease/chronic infantile neurologic, cutaneous, and articular syndrome (NOMID/CINCA) are all included in the
CAPS group. The genes responsible for all these autoinflammatory HPFS have been identified, and include $M E F V$ (encoding pyrin) responsible for FMF, TNFRSF1A for TRAPS, mevalonate kinase for HIDS, CIAS1/NLRP3 for CAPS, and the PSTPIP1 gene responsible for PAPA syndrome. These are relatively rare diseases but are associated with increased mortality and morbidity due to an increased potential for development of amyloidosis and other complications [2].

The wider spectrum of autoinflammatory disease includes polygenic conditions with a predominantly innate immune component, such as Crohn's disease [2], as well as those major histocompatibility complex class I-associated conditions, including psoriasis, ankylosing spondylitis, reactive arthritis, and Behçet's disease, that are considered as intermediate diseases in the immunological disease continuum [1]. These conditions all show strong clinical overlap.

\section{Recent advances}

The NLRP3 mutations cause spontaneous activation of the inflammasome complex, leading to excessive interleukin (IL)-1 $\beta$ secretion (Figure 1). This excessive secretion is responsible for the clinical manifestations of CAPS, as well as playing a role in a number of other autoinflammatory diseases, including FMF and TRAPS. 
Figure I. Activation of the NLRP3 inflammasome leads to cleavage of pro-IL-I $\beta$, by caspase-I, into the mature IL-I $\beta$

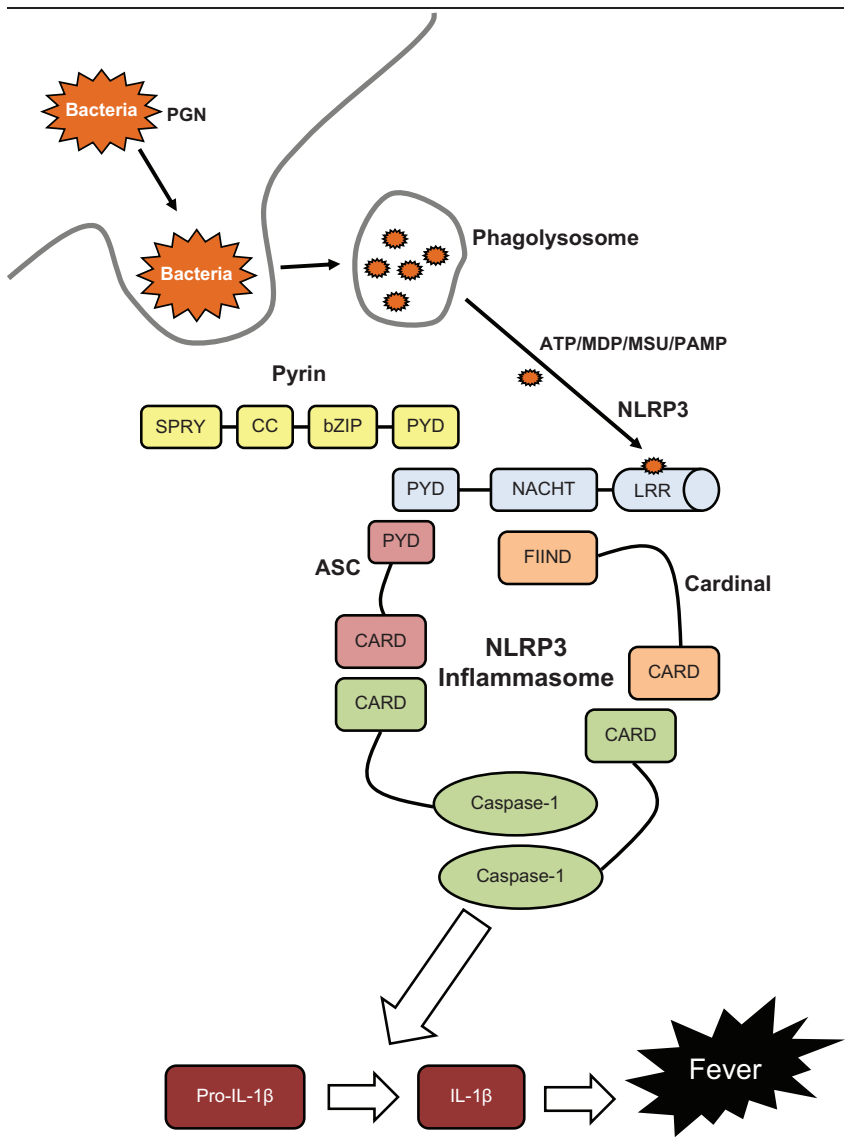

Activation usually occurs through stimulation with microbial peptides, such as peptidoglycan (PGN), monosodium urate (MSU), and other pathogenassociated molecular patterns (PAMP). These PAMP are recognised by the leucine-rich repeat domain (LRR) of NLRP3. Mutations in the NACHT domain of NLRP3 cause spontaneous activation of the this multimeric protein complex, which leads to over-production of IL-I $\beta$. This excessive secretion of IL-I $\beta$ is mainly responsible for the clinical manifestations of the cryopyrinopathies (CAPS) and plays a role in all periodic fevers. Screening for mutations in the NACHT domain of NLRP3 is routinely carried out for diagnosis of CAPS; however mutations are only found in around $50 \%$ of cases. ASC, apoptosis-associated speck-like protein containing a CARD; bZIP, basic leucine zipper; CARD, caspase recruitment domain; CC, coiled coil; FIIND, function to find domain; MDP, muramyl dipeptide; PYD, pyrin domain; SPRY, spIA/ryanodine receptor domain.

In vitro and murine studies have shown that the B30.2 domain of pyrin interacts directly with caspase- 1 to modulate IL-1 $\beta$ production, resulting in high levels of IL-1 $\beta[3]$.

Until recently the mainstay of treatment for CAPS has been anakinra, a recombinant non-glycosylated human IL-1R antagonist, which blocks IL-1 $\beta$ from binding to its receptor with remarkable efficacy [4]. Two alternative
IL-1 antagonists are now available. Studies have shown that rilonacept, which acts as a soluble decoy receptor for both IL-1 $\beta$ and IL-1 $\alpha$, can produce rapid symptomatic improvement [5]. A fully humanised monoclonal antibody against IL-1 $\beta$, canakinumab, has also been approved for use in FCAS and Muckle-Wells syndrome. A published phase III clinical study demonstrated that canakinumab was effective in CAPS patients, with 34 of 35 patients achieving a complete clinical response within 15 days [6].

A pilot study has shown that IL- $1 \beta$ inhibition by anakinra is also effective in both acute gout [7] and resistant pseudogout [8]. Following on from this success, a proof-of-concept study of rilonacept was conducted in 10 patients with chronic gout; this was the first controlled and blinded study of an IL-1 blocking agent in this condition [9]. Rilonacept has the advantage of a long plasma half-life and the ability to bind to IL-1 $\beta$ with high affinity [10]; it also binds to both IL-1 $\alpha$ and the IL-1 receptor antagonist (IL-1ra) but with less affinity [11].

Treatment of the autoinflammatroy disorder TRAPS is also moving towards targeted IL-1 $\beta$. Therapy had traditionally involved corticosteroids, to which the fever is particularly responsive [12], and then progressed onto anti-tumour necrosis factor (anti-TNF) agents, which have been used with varying degrees of success. Etanercept, a recombinant human TNFR2-Fc fusion protein, has demonstrated good efficacy [13] whereas the monoclonal anti-TNF antibody infliximab may induce a paradoxical inflammatory reaction and should be avoided in suspected cases of TRAPS [14,15]. More recently, anakinra has been used to treat TRAPS patients [16], with one study demonstrating a prompt response in all patients, with normalisation of acute phase reactant levels [17].

A novel neonatal autoinflammatory disease, deficiency of IL-1ra (DIRA), has recently been described, caused by recessive mutations in the IL-1 receptor gene (IL1RN) with heterozygous carriers being asymptomatic $[18,19]$. These mutations, identified by two separate groups, result in a truncated protein that is not secreted, causing cells to be hyper-responsive to IL-1 $\beta$ stimulation. Disease manifestations include multifocal osteomyelitis, periostitis, and pustulosis; the condition can be fatal but surviving children have been treated successfully with anakinra, resulting in a rapid reduction of the skin eruptions and inflammation, along with regression of the bone abnormalities. These studies suggest that treating DIRA patients promptly with IL-1ra may prevent development of painful and debilitaing bone abnormalities [18]. 
A subset of systemic onset juvenile idiopathic arthritis (SoJIA) has been classified as an autoinflammatory disease in recent years. A leukocyte gene expression study of SoJIA patients identified a unique IL-1 $\beta$ signature when compared to controls, and this signature changed significantly in patients undergoing IL-1 $\beta$ blockade [20]. However, subsequent studies have failed to replicate the IL-1 $\beta$ signature [21] and excessive IL-1 $\beta$ secretion was not found in SoJIA patients at any stage of therapy in one report [22]. Other potential markers of SoJIA have also been reported; serum levels of the myeloid-related proteins 8 and 14 (MRP-8 and MRP-14) were significantly higher in SoJIA patients than in healthy or other disease controls [23]. Apart from IL-1 blockade, treatment with the anti-IL-6 receptor monoclonal antibody tocilizumab has also proved to be effective in SoJIA patients [24], providing another promising therapeutic avenue in this previously difficult to manage disorder.

In the wider disease spectrum, genes with functions in the innate immune system have also been identified as conferring risk to Crohn's disease, thereby supporting an autoinflammatory component in the pathogenesis. The susceptibility genes include two autophagy genes, ATG16L1 [25] and IRGM [26], and a regulatory region downstream of NLRP3 [27]. Autophagy is linked to innate immunity by delivery of microbial degradation products to intracellular pathogen recognition receptors [28]. TNF blockade is the treatment of choice in Crohn's disease, but IL-1 $\beta$ blockade is ineffective and may aggravate the condition [29].

\section{Implications for clinical practice}

The increased clinical awareness of autoinflammatory disease and the remarkable effectiveness of IL-1 blockade have raised a number of questions about which compound (short, intermediate, or long acting) to use in a variety of these disorders, and how early to intervene in the course of disease in order to prevent the development of skeletal and central nervous system defects in conditions such as CAPS and DIRA. It is possible that prophylactic IL-1 inhibition will be employed in the future to avoid long-term sequelae after positive screening for these conditions.

Sustained IL-1 suppression may have potentially serious long-term effects, which are currently unknown. Furthermore, biologics-based therapies are expensive and not readily available for all patients who might benefit; for example, IL-1 $\beta$ inhibition is not in routine use for gout but may have a therapeutic advantage over hypouricaemic therapies in more severe cases. Encouraging results have been obtained from the use of small molecules, such as caspase-1 inhibitors, as an alternative approach to biologics-based therapies. The orally available pro-drug VX-765, a potent, selective inhibitor of caspase-1, blocked IL-1 $\beta$ secretion in peripheral blood mononuclear cells from FCAS patients and this may represent a future therapeutic option [30].

\section{Abbreviations}

CAPS, cryopyrin-associated periodic syndrome; DIRA, deficiency of IL-1ra; FCAS, familial cold autoinflammatory syndrome; FMF, familial Mediterranean fever; HIDS, hyperimmunoglobulinemia $\mathrm{D}$ with periodic fever syndrome; HPFS, hereditary periodic fever syndromes; IL, interleukin; IL-1ra, IL-1 receptor antagonist; NOMID/ CINCA, neonatal onset multisystem inflammatory disease/chronic infantile neurologic, cutaneous, and articular syndrome; PAPA, pyogenic arthritis, pyoderma gangrenosum, and acne; SoJIA, systemic onset juvenile idiopathic arthritis; TNF, tumour necrosis factor; TRAPS, tumor necrosis factor receptor-associated periodic syndrome.

\section{Competing interests}

The authors declare that they have no competing interests.

\section{References}

I. McGonagle D, McDermott MF: A proposed classification of the immunological diseases. PLOS Med 2006, 3:e297.

2. McGonagle D, Aziz A, Dickie, LJ, McDermott MF: An integrated classification of pediatric inflammatory diseases, based on the concepts of autoinflammation and the immunological disease continuum. Pediatr Res 2009, 65:38R-45R.

3. Chae J, Wood G, Masters SL, Richard K, Park G, Smith BJ, Kastner DL: The B30.2 domain of pyrin, the familial Mediterranean fever protien, interacts directly with caspase-I to modulate IL-Ibeta production. Proc Natl Acad Sci U S A 2006, 103:9982-7.

4. Goldbach-Mansky R, Dailey NJ, Canna SW, Gelabert A, Jones J, Rubin BI, Kim HJ, Brewer C, Zalewski C, Wiggs E, Hill S, Turner ML, Karp BI, Aksentijevich I, Pucino F, Penzak SR, Haverkamp MH, Stein L, Adams BS, Moore TL, Fuhlbrigge RC, Shaham B, Jarvis JN, O'Neil K, Vehe RK, Beitz LO, Gardner G, Hannan WP, Warren RW, Horn W, et al.: Neonatal-onset multisystem inflammatory disease responsive to interleukin-Ibeta inhibition. N Engl J Med 2006, 355:581-92.

5. Hoffman HM, Throne ML, Amar NJ, Sebai M, Kivitz AJ, Kavanaugh A, Weinstein SP, Belomestnov P, Yancopoulos GD, Stahl N, Mellis SJ: Efficacy and safety of rilonacept (interleukin-I trap) in patients with cryopyrin-associated periodic syndromes: Results from two sequential placebo-controlled studies. Arthritis Rheum 2008, 58:2443-52.

6. Lachmann HJ, Kone-Paut I, Kuemmerle-Deschner JB, Leslie KS, Hachulla E, Quartier P, Gitton X, Widmer A, Patel N, Hawkins PN; Canakinumab in CAPS Study Group: Use of canakinumab in the cryopyrin-associated periodic syndrome. N Engl J Med 2009, 360:2416-25

7. So A, De Smedt T, Revaz S, Tschopp J: A pilot study of IL-I inhibition by anakinra in acute gout. Arthritis Res Ther 2007, 9: R28.

8. McGonagle D, Tan AL, Madden J, Emery P, McDermott MF: Successful treatment of resistant pseudogout with anakinra. Arthritis Rheum 2008, 58:631-3. 
9. Terkeltaub R, Sundy JS, Schumacher HR, Murphy F, Bookbinder S, Biedermann S, Wu R, Mellis S, Radin A: The interleukin I inhibitor rilonacept in treatment of chronic gouty arthritis: results of a placebo-controlled, monosequence crossover, non-randomised, single-blind pilot study. Ann Rheum Dis 2009, 68: 1613-7.

10. Economides AN, Carpenter LR, Rudge JS, Wong V, Koehler-Stec EM, Hartnett C, Pyles EA, Xu X, Daly TJ, Young MR, Fandl JP, Lee F, Carver S, McNay J, Bailey K, Ramakanth S, Hutabarat R, Huang TT, Radziejewski C, Yancopoulos GD, Stahl N: Cytokine traps: multicomponent, high affinity blockers of cytokine action. Nat Med 2003, 9:47-52.

II. Dinarello CA: Setting the cytokine trap for autoimmunity. Nat Med 2003, 9:20-2.

12. Church LD, Churchman SM, Hawkins PN, McDermott MF: Hereditary auto-inflammatory disorders and biologics. Springer Semin Immunopathol 2006, 27:494-508.

13. Nowlan ML, Drewe E, Bulsara H, Esposito N, Robins RA, Tighe PJ, Powell RJ, Todd I: Systemic cytokine levels and the effects of etanercept in TNF receptor-associated periodic syndrome (TRAPS) involving a C33Y mutation in TNFRSFIA. Rheumatology 2006, 45:3I-7.

14. Jacobelli S, André M, Alexandra JF, Dodé C, Papo T: Failure of antiTNF therapy in TNF receptor I-associated periodic syndrome (TRAPS). Rheumatology 2007, 46: I2 II-2.

15. Nedjai B, Hitman GA, Quillinan N, Coughlan RJ, Church L, McDermott MF, Turner MD: Proinflammatory action of the antiinflammatory drug infliximab in tumor necrosis factor receptor-associated periodic syndrome. Arthritis Rheum 2009, 60:619-25.

16. Simon A, Bodar EJ, van der Hilst JC, van der Meer JW, Fiselier TJ, Cuppen MP, Drenth JP: Beneficial response to interleukin I receptor antagonist in TRAPS. Am J Med 2004, 1 I 7:208-10.

17. Gattorno M, Pelagatti MA, Meini A, Obici L, Barcellona R, Federici S, Buoncompagni A, Plebani A, Merlini G, Martini A: Persistent efficacy of anakinra in patients with tumor necrosis factor receptor-associated periodic syndrome. Arthritis Rheum 2008, 58:1516-20.

18. Aksentijevich I, Masters SL, Ferguson PJ, Dancey P, Frenkel J, van Royen-Kerkhoff A, Laxer R, Tedgard U, Cowen EW, Pham TH, Booty M, Estes JD, Sandler NG, Plass N, Stone DL, Turner ML, Hill S, Butman JA, Schneider R, Babyn P, El-Shanti HI, Pope E, Barron K, Bing X, Laurence A, Lee CC, Chapelle D, Clarke GI, Ohson K, Nicholson M, et al.: An autoinflammatory disease with deficiency of the interleukin-I-receptor antagonist. N Engl J Med 2009, 360:2426-37.

\section{Changes Clinical Practice}

F1000 Factor 6.4 Must Read

Evaluated by Albert Yan 12 Jun 2009, Michael McDermott 24 Jun 2009

19. Reddy S, Jia S, Geoffrey R, Lorier R, Suchi M, Broeckel U, Hessner MJ, Verbsky ]: An autoinflammatory disease due to homozygous deletion of the ILIRN locus. N Engl J Med 2009, 360:2438-44.

FI000 Factor 9.0 Exceptional

Evaluated by Daniel Remick 20 Jul 2009

20. Allantaz F, Chaussabel D, Stichweh D, Bennett L, Allman W, Mejias A, Ardura M, Chung W, Wise C, Palucka K, Ramilo O, Punaro M, Banchereau J, Pascual V: Blood leukocyte microarrays to diagnose systemic onset juvenile idiopathic arthritis and follow the response to IL-I blockade. J Exp Med 2007, 204:2131-44.

FI000 Factor 3.0 Recommended

Evaluated by Andreas Gruetzkau 07 Apr 2008
2I. Barnes MG, Grom AA, Thompson SD, Griffin TA, Pavlidis P, Itert L, Fall N, Sowders DP, Hinze CH, Aronow BJ, Luyrink LK, Srivastava S, Ilowite NT, Gottlieb BS, Olson JC, Sherry DD, Glass DN, Colbert RA: Subtype-specific peripheral blood gene expression profiles in recent-onset juvenile idiopathic arthritis. Arthritis Rheum 2009, 60:2102-12.

22. Gattorno M, Piccini A, Lasigliè D, Tassi S, Brisca G, Carta S, Delfino L, Ferlito F, Pelagatti MA, Caroli F, Buoncompagni A, Viola S, Loy A, Sironi M, Vecchi A, Ravelli A, Martini A, Rubartelli A: The pattern of response to anti-interleukin-I treatment distinguishes two subsets of patients with systemic-onset juvenile idiopathic arthritis. Arthritis Rheum 2008, 58:1505-15.

23. Frosch M, Ahlmann M, Vogl T, Wittkowski H, Wulffraat N, Foell D, Roth J: The myeloid-related proteins 8 and 14 complex, a novel ligand of toll-like receptor 4 , and interleukin-Ibeta form a positive feedback mechanism in systemic-onset juvenile idiopathic arthritis. Arthritis Rheum 2009, 60:883-91.

24. Yokota S, Imagawa T, Mori M, Miyamae T, Aihara Y, Takei S, Iwata N, Umebayashi H, Murata T, Miyoshi M, Tomiita M, Nishimoto N, Kishimoto T: Efficacy and safety of tocilizumab in pateints with systemic-onset juvenile idiopathic arthritis: a randomised, double-blind, placebo-controlled, withdrawal phase III trial. Lancet 2008, 371:998-1006.

FI000 Factor 6.0 Must Read

Evaluated by Frank Pessler 26 Jan 2009

25. Cummings JR, Cooney R, Pathan S, Anderson CA, Barrett JC, Beckly J, Geremia A, Hancock L, Guo C, Ahmad T, Cardon LR, Jewell DP: Confirmation of the role of ATGI6LI as a Crohn's disease susceptibility gene. Inflamm Bowel Dis 2007, 13:941-6.

26. Parkes M, Barrett JC, Prescott NJ, Tremelling M, Anderson CA Fisher SA, Roberts RG, Nimmo ER, Cummings FR, Soars D, Drummond $H$, Lees CW, Khawaja SA, Bagnall R, Burke DA, Todhunter CE, Ahmad T, Onnie CM, McArdle W, Strachan D, Bethel G, Bryan C, Lewis CM, Deloukas P, Forbes A, Sanderson J, Jewell DP, Satsangi J, Mansfield JC; Wellcome Trust Case Control Consortiuum, et al:: Sequence variants in the autophagy gene IRGM and multiple other replicating loci contribute to Crohn's disease susceptibility. Nat Genet 2007, 39:830-2.

FI000 Factor 6.0 Must Read

Evaluated by Jonathan Howard 15 Jun 2007

27. Villani AC, Lemire M, Fortin G, Louis E, Silverberg MS, Collette C, Baba N, Libioulle C, Belaiche J, Bitton A, Gaudet D, Cohen A, Langelier D, Fortin PR, Wither JE, Sarfati M, Rutgeerts P, Rioux JD, Vermeire S, Hudson TJ, Franchimont D: Common variants in the NLRP3 region contribute to Crohn's disease susceptibility. Nat Genet 2009, 4I:7I-9.

FI000 Factor 3.0 Recommended Evaluated by Michael McDermott 06 Feb 2009

28. Delgado M, Singh S, De Haro S, Master S, Ponpuak M, Dinkins C, Ornatowski W, Vergne I, Deretic V: Autophagy and pattern recognition receptors in innate immunity. Immunol Rev 2009, 227:189-202

29. Carter JD, Valeriano J, Vasey FB: Crohn disease worsened by anakinra administration. J Clin Rheumatol 2003, 9:276-277.

30. Stack JH, Beaumont K, Larsen PD, Straley KS, Henkel GW, Randle JC, Hoffman HM: IL-converting enzyme/caspase-I inhibitor VX765 blocks the hypersensitive response to an inflammatory stimulus in monocytes from familial cold autoinflammatory syndrome patients. J Immunol 2005, 175:2630-34. 